\title{
The Current Situation and Solving Strategies of MAYA Three-Dimensional Animation Teaching
}

\author{
Guo Shuguang \\ Fine Arts Department, Chifeng University \\ Chifeng, China
}

\begin{abstract}
In recent years, with the continuous improvement of the educational system in China, the way of making threedimensional animation has been increasing, which specifically includes the film and television animation design, cartoon animation design, advertisement animation design, digital media animation design and other MAYA design courses. The use of MAYA three-dimensional animation teaching can not only make the classroom teaching lively and vivid, but also improve the teaching quality and level of three-dimensional animation. This article puts forward some effective measures and suggestions on the current situation and existing problems of MAYA threedimensional animation teaching in order to improve the teaching level of three-dimensional animation.
\end{abstract}

Keywords-MAYA; Three-dimensional animation method; Teaching mode; Effective strategies

\section{INTRODUCTION}

In the information age, how to use MAYA threedimensional animation to make better animation has become a hot topic in the current school teaching development. In our country, MAYA three-dimensional animation syllabus has made it clear: "Let students learn to use Qt and C + + software for three-dimensional animation, use Houdini, Python, nCloth, $\mathrm{n}$ Particles and other software to beautify the effect of threedimensional animation, and further innovate MAYA threedimensional animation teaching mode."

\section{THE OVERVIEW OF MAYA THREE-DIMENSIONAL ANIMATION TEACHING}

MAYA is mainly an advanced three-dimensional animation software, which has its own simple operation, strong performance, excellent production and so on. MAYA three-dimensional animation teaching includes film and television animation, cartoon animation and advertising animation. The focus of the three different animation methods is not the same. The basic steps of MAYA three-dimensional animation teaching are model reflection, material mapping production, animation, post-editing and power effects production [1].

\section{A. Film and Television Animation Production}

Film and Television animation production is mainly based on three-dimensional text. It integrates DFusion, After Effects and Shake software to produce colorful film and television effects. It also widely uses fluid effects and gradually converts the TGA format to IFF format, so as to enhance the quality and level of film and television animation production.

\section{B. Cartoon Animation Production}

Cartoon animation mainly uses model making, character animation and material rendering production. It uses people, machinery, animals, flowers and other complex models for learning and production. It uses polygons and curved surfaces for building models, and then builds models by using curve and curved surface models. Character cartoon animation production needs to use the laws of movement, linear animation, animation technology and other new technologies to organize teaching.

\section{Advertisement Animation Production}

Advertisement animation production refers to the combination of path animation, constraint technology, power application technology and binding technology. It produces free fall, flat throw technology, collision technology, and founder technology, so as to produce different ads. For example, special effects such as smoke, lightning, stories and so on can be incorporated in the advertising production.

\section{THE GREAT SIGNIFICANCE OF MAYA THREE- DIMENSIONAL ANIMATION TEACHING}

\section{A. It is helpful to Improve Students' Enthusiasm and Initiative.}

MAYA three-dimensional animation has many different modules, and each module's teaching content and focus are different. Teachers can take advantage of these advantages and characteristics and guide students to conduct their own reading and learning. The traditional teaching method which is based on teacher's teaching turns into the teaching method of active learning and exploration, so that students no longer passively accept and understand knowledge. This helps to improve students' enthusiasm and initiative in learning threedimensional animation [2]. For example, when learning the course of the "Basic Operation Method of MAYA ThreeDimensional Animation", teachers can compare the MAYA interface with the Windows interface. Through this comparative learning mode, students can fully mobilize their own initiative and think independently to solve the practical problems encountered in the learning process. 


\section{B. It is Helpful to Develop Students' Creative Thinking and Divergent Thinking.}

For different professional students, the requirements of MAYA three-dimensional animation are different, but we should pay attention to that students will always be the subject of classroom learning. Teachers should be people-oriented, meet the interests of students, individually teach according to personality differences, fully stimulate the potential of students, and develop students' creative thinking and divergent thinking [3]. For example, while learning "surface modeling", teachers can ask students to observe what color, type, and form of various cups they use in life and model them according to the characteristics of different cups. At the same time, teachers can encourage students to give full play to their imagination and draw their own cup. This not only can improve the quality and level of teaching, but also cultivate students' creativity.

\section{THE CURRENT SiTUATION AND PROBLEMS ENCOUNTERED IN MAYA THREE-DIMENSIONAL ANIMATION TEACHING}

MAYA is a three-dimensional animation software. It has incomparable superiority of other software. Although MAYA three-dimensional animation teaching has made some substantial progress in the actual development process, in the specific teaching process, there are still some problems: The first one is that MAYA three-dimensional animation teaching model is single and backward. Many schools simply equate three-dimensional animation teaching with computer teaching in the traditional sense. In the teaching process of MAYA three-dimensional animation, they often confine themselves to teachers' unilateral teaching and teachers become the main body of classroom teaching. Students are often in a passive learning and accepting position. Therefore, MAYA threedimensional animation teaching only stays on the surface, over-emphasis on teaching content and neglect practical teaching, so classroom teaching efficiency is low. The second one is that teachers who teach MAYA three-dimensional animation are conservative thinking. There is little communication between teachers and students in the class. Students' learning is confined to the class and there is very little time for students to practice after class. Students simply master the theory of three-dimensional animation, incompletely grasp the specific operation and drawing, and can not independently make their own satisfaction threedimensional animation. The third one is that MAYA threedimensional animation is a subject which has high requirements for professional knowledge and practical ability. If it stays in the traditional teaching contents and methods, it is not conducive to the formation of students' imagination thinking and divergent thinking. It can not make students really understand the value and significance of MAYA threedimensional animation.

\section{THE EFFECTIVE STRATEGIES OF OPTIMIZING THE MAYA THREE-DIMENSIONAL ANIMATION TEACHING}

\section{A. Using Scene Reproduction Method to Determine the Teaching Objectives}

In the teaching process of MAYA three-dimensional animation, we can use the scene reproduction method. This method reproduces the three-dimensional animation process which allows students to repeatedly learn the process of operation, and create a good and harmonious atmosphere for students to enable them to master MAYA three-dimensional animation in a relaxed and happy environment. This approach can also increase the attractiveness of the classroom, mobilize and stimulate students' enthusiasm and initiative [4]. At the same time, teachers can also use scenario rendering method to guide MAYA three-dimensional animation classroom teaching. Students and teachers should also communicate and interact with each other. Students can ask teachers questions that they do not understand. Teachers can ask students about whether they have mastered today's teaching content. This interactive exchange can not only improve the teaching quality of MAYA three-dimensional animation, but also optimize the teaching methods of MAYA three-dimensional animation, exert teaching advantages and clarify the teaching objectives and content of MAYA 3D animation.

\section{B. Building a Harmonious Relationship Between Teachers and Students to Carry Out Cooperative Education}

According to the different characteristics of each student's learning, teachers of MAYA three-dimensional animation should individually and reasonably arrange teaching content. Teachers operate one step, students follow the teachers to operate one step. This approach not only increases students' attention, but also increases the interaction between teachers and students [5]. In addition, teachers can also divide students into several different groups for group study. In accordance with the tasks assigned by the teacher, the students conduct regular learning, and then share the learning outcomes with teachers and communicate with each other, which can better build a harmonious relationship between teachers and students. Teachers should change their own teaching concepts, keep pace with the times, blaze new trails, innovate on the basis of practice and practice on the basis of innovation so as to enhance the enthusiasm and confidence of students in learning [6]. Schools should retrain their teachers and continuously improve teachers' professionalism and teaching ability so that teachers can establish lifelong learning goals.

\section{Combining the Theory with Practice to Optimize Teaching Effects.}

Teachers of MAYA three-dimensional animation can combine theory with practice. Students not only have to master the theoretical knowledge, but also should learn to practice. The ultimate goal of this professional teaching is to enable students to independently create MAYA threedimensional animation, design and produce outstanding works. For example: When using three-dimensional animation software, teachers can also be applied to their daily lives. At the end of the course, teachers can conduct a comprehensive 
assessment, and then summarize and improve the teaching objectives, optimize the teaching effects of MAYA threedimensional animation [7]. For example, when learning the content of "Accepting Panels and Instructions", teachers can teach the theory first, and let the students know the operation flow and order. Then according to the theory, le students use polygon segmentation tools, insert polygon tools and other practical operations to clarify the key and difficult of the theoretical knowledge, so as to improve students' capabilities of learning MAYA three-dimensional animation.

\section{Innovating Teaching Modes and Methods to Improve Teaching Level}

With the continuous improvement of our educational system, schools can not blindly follow the traditional teaching modes and methods. Schools should change the teaching philosophy and comprehensively use varieties of advanced technologies to improve the teaching quality and level of MAYA three-dimensional animation [8]. Schools should actively accept the new system and new things, update the traditional teaching methods, accurately locate the market dynamic information, ensure the smooth flow of information, and carry out teaching activities in an organized and planned manner, so as to cultivate more high-quality and professional three-dimensional animation talents. For example, when learning to render and post-synthesize, teachers should make students recognize the importance of post-synthesis for the whole MAYA three-dimensional animation and make them master the production process and method.

\section{CONCLUSION}

In summary, to improve MAYA three-dimensional animation teaching level and quality is the inevitable requirement for the development of current quality education. According to the personality and characteristics of different students, teachers use scene reconstruction method, constructing harmonious relationship with students to cooperate teaching, it also combine theory with practice, and optimize teaching effect so as to optimize MAYA threedimensional animation teaching effect, achieving the goal of three-dimensional animation teaching, and stimulate students' initiative and enthusiasm so that students can really fall in love with learning MAYA three-dimensional animation. In short, optimizing MAYA three-dimensional animation teaching effect requires the joint efforts of the schools, teachers and students, and only in this way can we cultivate more highquality talents for the society!

\section{REFERENCES}

[1] Wei Wang: The Teaching of Three-Dimensional Animation Production Software Maya [J], Artistic Sea, 2012, (6).

[2] Li Wu: Exploration on the Teaching Reform of Three-Dimensional Animation Software MAYA [J], Journal of Nanchang College of Education, 2011, 26(11):116-116.

[3] Hongxia Meng and Lei Duan: Discussion on the Reform and Implementation of Maya Three-Dimensional Animation Teaching[J], Journal of Tongling Vocational and Technical College,2 010,9(1):64-65.

[4] Wei Wang: The Teaching of Three-Dimensional Animation Production Software May [J], Artistic Sea, 2012, (6).

[5] Yu Qian and Ting Wu: Application of Example Method in Maya Teaching [J], New Campus (study), 2013(1).

[6] Chao Yang: Analysis and Thinking on the Teaching of ThreeDimensional Animation Based on MAYA [J], Electronics World, 2014, (4):155-156.

[7] Yajun Qin: Analysis and Thinking on the Teaching of ThreeDimensional Animation Based on MAYA in Colleges and Universities [J], Shenzhou (periodical appearing once every ten days), 2011, (10):4646.

[8] Hongxia Meng and Lei Duan: Discussion on the Reform and Implementation of Maya Three-Dimensional Animation Teaching[J], Journal of Tongling Vocational and Technical College, 2010, 9(1):64-65. 